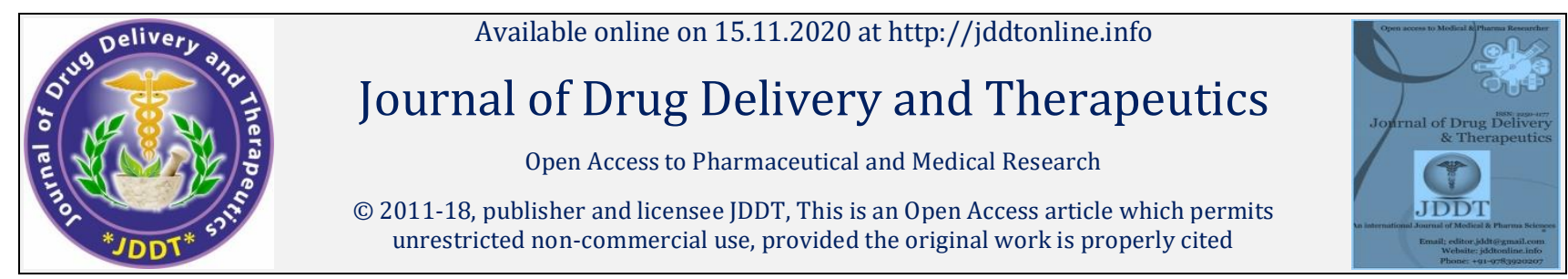

Open@Access

Review Article

\title{
A Review on Pharmacognostic and Therapeutic Uses of Rubia cordifolia
}

\author{
Ayesha Ali *, Mohd Aslam**, Shahid S Chaudhary*** \\ * PG Scholar, School of Unani Medical Education and Research, Jamia Hamdard, New Delhi, India \\ ** HOD, Professor, School of Unani Medical Education and Research, Jamia Hamdard, New Delhi, India \\ *** Assistant Professor, School of Unani Medical Education and Research, Jamia Hamdard, New Delhi, India
}

\begin{abstract}
In today's time research on plants has increased globally. There are thousands of plant species having good potential offering direct therapeutic effect individually or in combinations. Manjith a herbal drug also known as Indian madder with its botanical name Rubia cordifolia is an age old ethno-medicinal plant in India used as anti-oxidant, anti-inflammatory, anticancer, anti-bacterial, anti-androgenic, immune-modulator, hepatoprotective, astringent, tonic, antiseptic, de-obstruent, anti-dysenteric and efficient blood purifier, hence is extensively used against blood, skin and urinary diseases. This study is aimed at assessing the scientific evaluation of desi Rubia cordifolia in the course of pharmacognostical analysis to identify its various parts and to differentiate it from various adulterants, which mainly covers the macroscopic and microscopic features and its medicinal properties which are due to its richness in phytoconstituents such as quinines (anthraquinones), glycosides, saponins, tanins, alkaloids, hexapeptides, triterpenoids, steroids, phenols, and saccharids.
\end{abstract}

Keywords: Rubia cordifolia, Manjith, Fooh, ethno medicinal plant, Unani, pharmacological study

Article Info: Received 03 Sep 2020; $\quad$ Review Completed 12 Oct 2020; $\quad$ Accepted 23 Oct 2020; Available online 15 Nov 2020

Cite this article as:

Ali A, Aslam M, Chaudhary SS, A Review on Pharmacognostic and Therapeutic Uses of Rubia cordifolia, Journal of Drug Delivery and Therapeutics. 2020; 10(6):195-202 http://dx.doi.org/10.22270/jddt.v10i6.4514

*Address for Correspondence:

Ali Ayesha, School of Unani Medical Education and Research, Jamia Hamdard, New Delhi, India

\section{INTRODUCTION}

With an increasing use of modern medicines, last few decades has shown resistance in different pathologies, their related side effects and high cost of treatment, all this has led to change the focus to the type of medication to be used., progressively herbal medicine. Which in itself plays a basic role in preparation of different herbal formulation. In rural areas indigenous plants plays an important role in maintaining health and improving life. But identifying the drug with classical literature sometimes become difficult hence leading to misidentification of the plant, which may be due to complexities in herbal nomenclature. One such herbal drug which is rich in medicinal properties and is used in number of formulations for treating different ailments is Manjith. Manjith also known as Fooh in Unani system of medicine, is a species of flowering plant in the coffee family, Rubiaceae. It has been cultivated for a red pigment derived from the roots. ${ }^{1}$ Rubia denotes 'red' as their internal use imparts red color to breast milk and urine. 2 Roots of this plant having high medicinal value are recognized as official. It is ethno-medicinal plant, being used in Unani system of medicines for thousands of years. The drug is used for treating different ailments like arthralgia, arthritis, cephalalgia, cough, discolouration of the skin, dysmenorrhoea, emmenagogue, leucorrhoea, neuralgia, strangury, pectoral diseases, pharyngitis, general debility, hepatopathy, intermittent fevers, ophthalmopathy, otopathy, splenopathy, slow healing of broken bones, tubercular conditions of the skin and mucous tissue, tuberculosis and urethrorrhea 3 leucoderma, ulcers, urinary discharges, jaundice, and piles. 4 alzheimer, diabetes, cancer, acne, inflammation, allergy, enterocolitis, bacterial and viral infections. The aim of writing this review is to learn how to differentiate it from other related species and to bring attention to its multiple medicinal properties so that more benefits could be achieved from it.

\section{TAXONOMICAL CLASSIFICATION: 5}

\section{Kingdom: Plantae}

Class: Dicotyledoneae

Subclass: Sympetalae

Order: Rubiales 
Family: Rubiaceae

Genus: Rubia

Species: cordifolia

\section{VERNACULAR NAMES}

- $\quad$ Arabic- Arooqe sabagh and Foo ul sabagh 6

- Persian-Roomans 6

- $\quad$ English-Indian Madder 6

- Hindi-Majit and Manjit 6

- Bengali-Manjistha 6

- $\quad$ Urdu-Manjith 7

- Malayalum-Manjetti and Poont 7

- $\quad$ Marathi-Manjestha 7

- Kashmiri-Dandlu 7

- Manipuri-Moyam ${ }^{2}$

- $\quad$ Nepali-Manjito ${ }^{7}$

\section{DISTRIBUTION}

Rubia cordifolia linn is a flowering plant species from indigenous system of medicine. It commonly is known as Common Madder. Rubia cordifolia is a perennial climber, prickly or scabrous herb plant with red rhizomatous base and roots 8 , distributed in temperate and tropical forests of Africa and Asia especially in the hilly regions with an altitude ranging up to $3500 \mathrm{~m}^{2}$ while in south India adjacent to rivers and streams of upper ghats. ${ }^{9} R$. cordifolia can be easily found in hilly districts of India from N.W. Himalayas eastwards, ascending to $8000 \mathrm{ft}$ and southwards to Ceylon. Its roots are recognized as official. 10 It belongs to the family Rubiaceae, which comprises about 450 genera and 6500 species and includes trees, shrubs and infrequently herbs. ${ }^{11}$ About 15 species occur in India. ${ }^{12} \mathrm{R}$. cordifolia is a commonly found plant in almost all parts of south India. Manjishtha has three species: Rubia cordifolia (Indian maddar), Rubia akane (Asian maddar) and Rubia tinctorum (European or African maddar). ${ }^{13}$ The Indian Madder used for commercial purpose consists of short rootstocks with numerous straight,

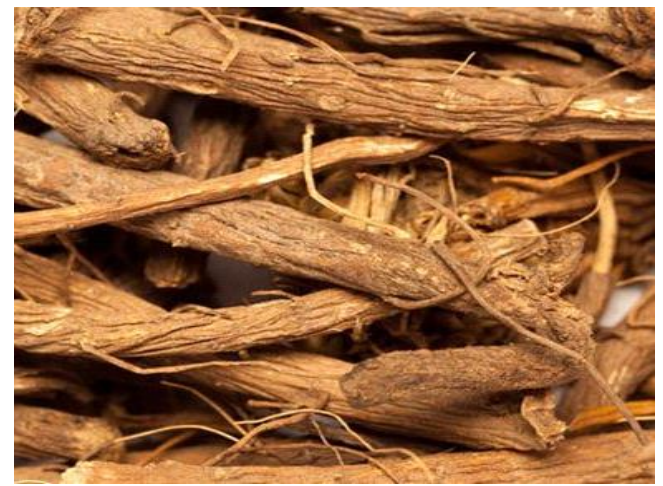

\section{The root}

Roots are long, cylindrical, flexuous, with a thin red bark. It is brittle, hard splintery in texture and hard to break. External bark gets peeled easily. Its surface is longitudinally furrowed. When peeled off inner surface is furrowed and dark purple in colour. ${ }^{4}$ Then cleaned and dried in the sun. ${ }^{17}$ cylindrical and smooth roots, about the size of a quill. These are covered with a thin brownish cork, which peels off in flakes, exposing a red-brown bark marked by longitudinal furrows.

\section{DESCRIPTION}

\section{- $\quad$ Parts Used}

\section{The stem}

The stems are often many yards long, rough, grooved, becoming slightly woody at the base, bark white, petioles quadrangular, divaricately branched, prickly-hispid, especially on the angles. Sometimes are glabrous and shining. ${ }^{14}$ It is slender, four angled with sharp recurved prickles on the ridges.

In transverse section of the stem it is seen as circular and smooth in outline. The Pyramidal hairs are present on the epidermis. Sclerenchymatous hypodermis is present in the stems, at its corner. The cortex is chlorenchymatous, hence photosynthetic. 15 The periderm formed of rectangular cell which are compactly arranged, thin walled and well developed with 4 to 11 layers. The periderm is followed by 8 to 12 layers of flattened compactly arranged parenchymatous cell, and is composed of xylem vessels in some section. Primary xylem is present towards the centre characterized by small vessels with xylem parenchyma cells.

Phloem parenchymal cells are very compactly arranged. Shape may vary from rectangular to spindle. The cortex is narrow and is 12 to 80 layered of longitudinally stressed, flattened parenchymatous cells. The secondary phloem is well developed and made up of 6-7 layers unlike primary phloem.

Medullary rays are uniseriate. Perimedullary sheath is narrow and it is made up of round or irregular thin-walled cells. ${ }^{16}$ Secondary xylem is made up of vessels, tracheids, fibers and xylem parenchyma. Vessels are large and uniformly arranged. ${ }^{16}$ Here larger vessels are at periphery and smaller one are towards inner boundary. It is diffusedly porous and are completely cylindrical. Cambium ring of the stem is represented by two layers.

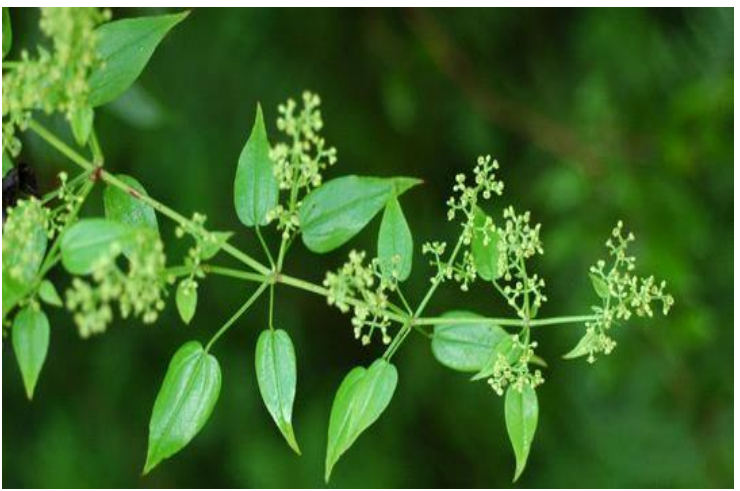

The cross-section of roots showed an outer 5-7 layer of cork tissue, which is known for storing tannin. Cambium is devoid of medullary rays. It has narrow cortex. The presence of anthraquinones is responsible for the red coloured appearance of the root.

\section{Mizaj (Temprament)}

Garam2 (hot) and Khushk2 (dry) ${ }^{18}$ 


\section{The leaves}

Leaves are highly variable, ovate lanceolate, 5-7 nerved, 2$10 \mathrm{~cm}$ long and 2-5 cm broad, occurring in whorls of 4-6. 1 Leaf base is slightly cordate. The lower leaves are larger than upper. The margins are with minute white prickles. Leaf is composed of single layer of epidermis and is covered with cuticle and possess pyramidal hairs. Leaf section showed single layered epidermis and also single layer of Palisade cells which are compactly packed, whereas the spongy cells are multilayered and loosely arranged. The dorsal aspect of midrib is made up of collenchymatous cells, which are found in 2-4 layers. 15 Vascular bundles are collateral and closed, conjoint and definite in numbers.

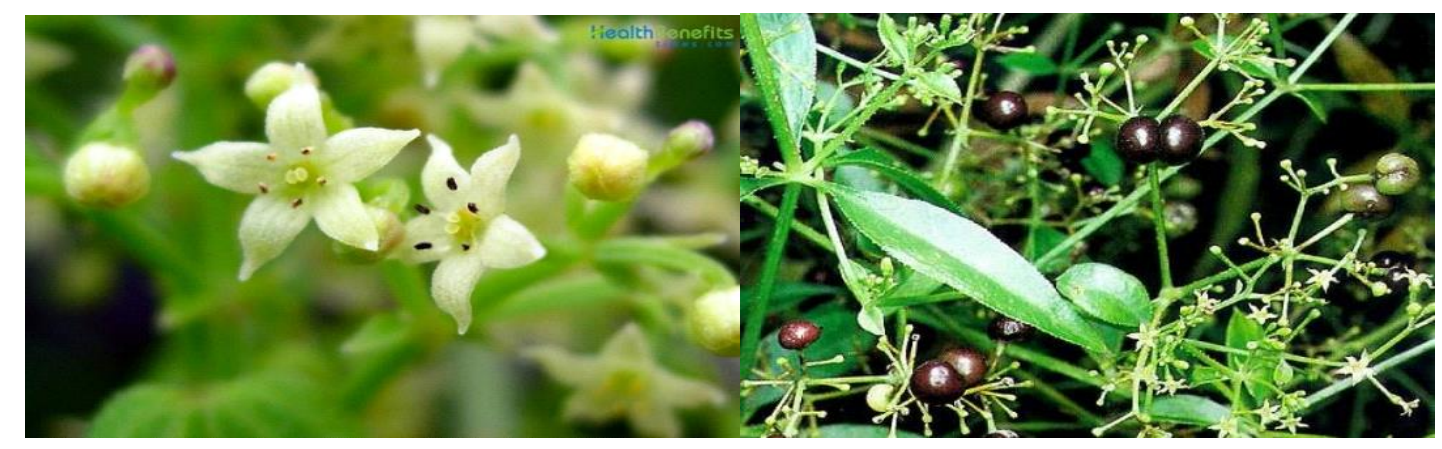

\section{The flower}

Flowers are cymes, fragrant, minute, whitish or greenish yellow. Plant carries flower and fruit in the month of August and october.

\section{The Fruit}

At the time of ripening the fruit is didymous or globose, smooth, shining and purplish black. ${ }^{19}$ It is fleshy, succulent and has red juice. ${ }^{20}$

\section{- $\quad$ Taste}

Sweet Bitter-acrid ${ }^{21}$

- Biomarkers of Rubia cordifolia responsible for therapeutical activities. 22

1. Rubiadin - Hepato-protective - Antioxidant

2. Alizarin - Anti-genotoxic

3. Mollugin- Antiadipogenesis - Antiplatelet

4. Alizarin, mollugin, lucidin - Potent COX-2 inhibitor $\mathrm{h}$

5. RA-70029 RA-XI, XII, XII, XIV30 - Antitumor

6. 1-hydroxytectoquinone31 - Anti-inflammatory

\section{- Substitute}

Kababa and Tij 23

\section{- $\quad$ Toxic}

Urinary bladder 23

\section{- Correctives}

Kateera and Aneeson 23

The constituent which is responsible for providing red colour to the herb is purpurin, while a yellow principle, a glucoside is manjistin, alzirin and garancin responsible for orange-red, and xanthine for yellow colour. 24 These colouring property of the plant was the reason that it was used for the commercial purpose as a dye stuff in old days. Earliest of the evidences which prove that it was used in Indus Civilisation for dying cotton (2300-1750 BC). Since then there is growth in dying industries according to various literary and archaeological survey. Some of the names like Indigo, Madder and Kermes where introduced all over the world by Indians during very early period. ${ }^{25}$ While its medicinal uses were first illustrated in a world famous book of China which is 2000 years old, based on pharmacy, named as Divine Farmers Materia Medica. ${ }^{26}$ The plant is used for both internal and external uses.

\section{- In Unani system of medicine: -}

In USM pharmacological actions of Majith are mentioned as: Mudire baul wa haiz (diuretic and emmenogauge) 6

Mufatte Sudah (deobsturent) 6

Musaffi khoon (blood purifier) ${ }^{6}$

Muskhkhin (calorific) 6

Jali (detergent) 6

Munqi jigar wa tihal (cleanser of liver and spleen) ${ }^{6}$

Detoxify kidney 27

$R$. cordifolia has been used to treat skin disorders, amenorrhoea, paralysis, jaundice, urinary tract obstructions, menstrual disorders (excessive or painful bleeding), renal stone, urinary disorders and blood detoxification. ${ }^{20}$ Some of its commonly used forms in USM are:

a) Joshandah of Manjith used for Mudire baul wa haiz 28

b) Safoofe Manjith 3gm given with Sikanjabeen for Mufatte Sudah and Yarqan (deobsturent and Jaundice) 28

c) Manjith along with vinegar works well for leukoderma and vitiligo. 6

- Some of the Classical Unani formulations which has $R$. cordifolia as an important ingredient:

- Halwae Gheekwar 29

- $\quad$ Dawaul Kurkum kabir 29

- $\quad$ Safoof Khas 29

- $\quad$ Safoof Musaffi khaas 29

- $\quad$ Majoon Dabeedul ward 29

- $\quad$ Majoon Suparipak 29

- $\quad$ Arq Anannas 29

- Roghan Ahmar Jadeed 30

- Sadri 30 
- $\quad$ Aqras Mur 31

- Majoon Alkula 32

- $\quad$ Majoon e Hafiz ul Ajsad 32

- Traditional uses:

There are numerous Indian folk medicines which are composed of Genus Rubia for treating ailments like healing wounds, inflammation and skin infections.

Traditionally the plant has been used as anthelmintic, antiseptic, constipating, diuretic, astringent, thermogenic, antidysenteric, anti-inflammatory, antipyretic, analgesic, anodyne, galactopurifier, febrifuge, rejuvenating and tonic. 33

\section{- In other Indigenous Systems}

Charak a vedic physician has used its dry fruit to treat ailment of spleen and skin disorders. ${ }^{34}$ In classic Ayrurvedic script Sushrutasamhita it is documented for bleeding piles.

Mollugin one of the active component was commonly used in Chinese medicine for the treatment of inflammatory diseases like arthritis and uteritis. 35

In Tibetan system of medicine, the stem is used to treat blood disorders, spreading fever of kidneys and intestines. ${ }^{36}$

In Philippines decoction of root is used to treat urinary disorders, while in korea, to treat rheumatism, jaundice and urinary disorders. ${ }^{37}$

Whereas in India, use to treat irregular mensturation and ear diseases in Sikkim, 38 to relieve uterine pain in tribes of Maharashtra, 39 tribes of Kerela use it to treat skin diseases, 40 to treat diarrhoea and dysentery in Odisha, 41 in Konda Dora tribes of A.P pills are used which are orally administered on empty stomach to treat jaundice 42 Vanraji tribes of Kumaun Himalaya use it with honey as a cure for acne and dark spots on face. 43

The administration of root decoction in the treatment of diabetes has been documented in 2010 survey. ${ }^{44}$

It is an excellent expectorant especially used in infants to relieve cough, cold and respiratory problems. 45 In the Cape Province, natives take a decoction of the leaf or root for pleurisy and other inflammatory conditions of the chest. 12

Roots were used for treating stones of kidney, bladder and gall bladder. ${ }^{46}$

$R$. cordifolia decoction is used to reduce scarring of the umbilical cord post birth. Primarily done in Uganda. 47

It has been used to provide relief from heat and itching in eczema, psoriasis, scabies and herpes. It has shown successful results in the treatment of vitiligo when given with honey. 26

\section{PHYTOCHEMISTRY}

This includes anthraquinones, iridoids, hexapeptides, rubiprasins, quinones, and triterpenoids. ${ }^{48}$ Anthraquinone, anthraquinone glycoside, napthaquinone, napthaquinone glycoside, furomollngin, mollugin, alizarin, lucidine, pimeveroside, ruberythric acid, purpurin, xanthopurpurin, cyclohexapeptide, alkaloid and lignan have been reported from rubia species. 49 Rubiadin is the major chemical constituent of this plant considered as a marker compound used in the quality control of this plant. 50 Purpurin is the major anthraquinone present in Rubia cordifolia. 1 Coumarins have been reported for the first time in roots and stems of $R$. cordifolia. It lacked flavonoids, which was a major finding in its another species, i.e R. tinctorium. Which is frequently used as a substitute of $R$. cordifolia. ${ }^{51}$

The roots contains many quinones, like mangistin, alizarin, mollugin, furomollugin ,1-hydroxy,2-methoxy anthraquinone,3- dimethoxy 2 carboxy anthraquinone, rubiprasin $\mathrm{A}, \mathrm{B}, \mathrm{C}, .52$

Some newly found anthraquinones in its roots are cordifoliol and cordifodiol. While purpurin is the major anthraquinone to be extracted from it.

\section{PHARMACOLOGICAL ACTIONS}

\section{Anti-inflammatory Effect}

During a rapid development of a model edema, manjistin along with purpurin has shown anti-proliferative action. 48

There is involvement of inflammatory mediators in the conditions like arthritis, asthma and in different inflammatory disorders, which are produced through lipoxygenase enzyme pathway. In a study the aqueous extract of rubia has been found effective in inhibiting the pathway. ${ }^{53}$

The extract Rubia cordifolia, Linn. was used to study the antiinflammatory effect in rats with carrageenan paw oedema. Where animals were given ethanolic and alcoholic extract of the rubia. Chronic administration of ethanolic extract decreased the humoral and cell-mediated immune response, phagocytosis, phagocytosis index. 54

\section{Wound Healing Activity}

Root extract of $R$. cordifolia has reported to be effective wound healer in experimental models. 55

A formulation of $R$. cordifolia along with some other herbal drugs were tested for their wound healing properties, where it proved to be capable of contracting the wound and promote epithelisation. 56

Ethanolic extract and the hydrogel formulation of roots were found to be effective in the functional recovery and healing of wounds and also showed histo-pathological alterations. 57

\section{Diuretic}

The hydro-alcoholic extract as well as the ethanol extract has shown significant electrolyte excretion and increase in urine volume in a dose dependent manner. 58

In another experiment to see the diuretic activity of the hydro-alcoholic extract of roots of $R$. cordifolia, dose of the extract was given according to weight of the animal, the extract showed a significant dose dependent increase in urine volume and electrolyte excretion. And showed better clearance or creatinine than furosemide. 59

\section{Antimicrobial}

Root extract of $R$. cordifolia has shown its effectiveness against various pathogenic bacteria's, like Klebsiella pneumonia, its constituents such as anthraquinones and flavonoids suppressed the active dphytopathogens of Gossypium, daucosterol possess antibacterial activity. 60

The green synthesized silver nanoparticles using root extract of $R$. cordifolia was highly effective against bacterial pathogens like Pseudomonas aeroginosa, Shigella spp, Plesiomonas shigelloides and Vibrio parahaemolyticus, and they had highest antimicrobial effect against Pseudomonas aeroginosa and Plesiomonas shigelloides. 61

The chloroform and the methanolic extracts reported to have antibacterial activity on gram-positive strains, although gram 
negative was also inhibited by the methanolic extracts in a dose dependent manner. The extract is significantly active against Bacillus subtilis and Staphylococcus aureus compared to streptomycin and penicillin G. 62

Many compounds have been isolated from the roots of $R$. cordifolia L.by established chemical and spectroscopic methods, where many compounds showed antibacterial activities. 63

Though furomollugin and mollugin has little effect on the viability of the cells, but it strongly suppresses the secretion of hepatitis B surface antigen in human hepatoma Hep3B cells. 64

\section{Radioprotective}

When $R$. cordifolia extract was administered intraperitoneally before the radiation exposure it provided significant protection against radiation induced lipid peroxidation, hemopoietic injury and genotoxicity. The alcoholic extract of $R$. cordifolia possess significant radioprotective potential, that might be due its antioxidant, anti-inflammatory, metal chelation and free radicle scavenging potential. 65

The aqueous extract of $R$. cordifolia effectively prevents Single strand breaks induced in plasmid pBR322 DNA following ionizing radiations. 66

Highest antioxidant potential of $R$. cordifolia leaves is found in methanolic extract. This free radical scavenging protocol is efficient for $R$. cordifolia and makes it potent for the production of biologically active compounds at a comparable rate to commercially available antioxidants. 67

\section{Anti-Adipogenic}

Anti-adipogenic activity of 2-carbomethoxy-2, 3- epoxy-3prenyl-1, 4-naphthoquinone (CMEP-NQ) was found to be effective on apoptosis, cell viability and adipogenesis in 3T3L1 preadipocytes. ${ }^{1}$

$R$. cordifolia extract in treated animals has lead reduction in Lipid peroxidation in the kidney and liver tissues. ${ }^{24}$

\section{Gastro-protective}

$R$. cordifolia extract has shown significant protection against gastric ulcer in a much better way than ranitidine in an experiment done on rats. 68

In an experiment where wistar rats where used and were treated the chloroform extract of $R$. cordifolia, it can be attributed to decrease gastric acid along with strengthening of the mucosal defensive mechanism by prostaglandin synthesis and antioxidant potency of the drug. 69

In a study where hydroalcoholic extract of $R$. cordifolia was tested upon animals, it suggested that it can protect indomethacin-induced enterocolitis in rats and may be beneficial in patients with inflammatory bowel diseases. 70

\section{Anti-convulsant}

In an experiment, rats where tested by giving them chemoconvulsants and maximum electric shock. But when they were given triterpenes, extracted from $R$. cordifolia, it inhibited the seizures by raising the brain GABA and Serotonin (5-HT). ${ }^{71}$

\section{Immunity enhancing activity}

The ethanolic extracts of the whole plant of $R$. cordifolia was given to rat model, who were given immunosuppressive drug, phosphamidon. The extract improved both type of immunity, cell-mediated and humoral. Also a significant suppression of DTH (Delayed type hyper sensitivity reaction) was noticed. It was observed that the extracts, of the plant acted as a potentiator of DTH. ${ }^{11}$

In another study the administration of ethanolic plant extracts to cyclophosphamide exposed animals resulted in enhanced immune responses. 72

\section{Antioxidant}

Anti-oxidant present in abundance in the root of $R$. cordifolia is rubiadin a dihydroxyanthraquinones, which prevents lipid peroxidation induced by FeSO4 and t-butylhydroperoxide ( $\mathrm{t}$ BHP) in a dose dependent manner. 58

It also contains antioxidants like alizarin and rubiadin, which prevents peroxidation. ${ }^{73}$

The antioxidants present in herb significantly inhibits FeSO4 induced lipid peroxidation and glutathione depletion. This antioxidant property is due to direct interaction with iron. ${ }^{74}$

The study highlighted the importance of $R$. cordifolia as an alternative system of medicine for parkinsonism due to its significantly active antioxidant property, that might be due to its anticholinergic action. Phenolic compounds are responsible for the action. ${ }^{75}$

Hexane and ethyl acetate fractions of root showed maximum free radical scavenging activity due to the presence of anthraquinones and glycosides in it. Hence $R$. cordifolia extract can protect peroxidation and can reduce glutathione content in rat liver homogenate compared to vitamin $\mathrm{E}$ and parabenzoquinone. ${ }^{76}$

\section{Anti-acne}

Mentholic extract of $R$. cordifolia has shown anti-proliferative action against Propionibacterium. acnes. 77

It is proved to be effective against TNFalpha and mildly against IL-8.

It is regarded as astringent and useful in external inflammations, skin diseases. 78

\section{Anti-cancerous}

$R$. cordifolia had shown an increase in leukocyte count in leucopenia ${ }^{79} R$. cordifolia is reported to be active against a diversified panel of cancer cell lines, such as P388, L1210, L5178Y, B16 melanoma, Lewis lung carcinoma, and sarcoma180. 80

Mollugin an active antiproliferative principle, obtained by bioassay-monitored fractionation using a human colon cancer (Col2) cell line. ${ }^{81}$

$R$. cordifolia is promisingly cytotoxic and they might have antitumor activity against myeloid leukaemia and Histolytic lymphoma. 82

Chloroform extract of $R$. cordifolia consists of mollugin, furomollugin and dehydro-a-lapchone. Mollugin inhibits passive cutaneous anaphylaxis (PCA) and dose protection of mast cell from degranulation in rats. It also exhibited considerable activity against lymphoid leukaemia (P338) in mice. 83

The methylene chloride fraction from the roots of $R$ cordifolia showed strong cytotoxicity against HT-29 and MCF-7 cell lines, as well as DNA topoisomerase I and II inhibitory activities. 84

\section{Hepatoprotective activity}

Aqueous-menthol extract of $R$ cordifolia was used to investigate hepatoprotective activity against acetaminophen 
and CCl4-induced hepatic damage, which proved to be protective in nature. 85

It has been found to be effective against acute and chronic hepatitis caused by the hepatitis B virus (HBV) in human hepatoma cells (Hep 3B). The quinone derivatives were thought to be the active components 73

The quinone derivatives are known to have hepatoprotective effect in animals. In an experiment methanolic extract has shown protective action against the liver thioacetamideinduced hepatotoxicity. 86

The study indicated that rubiadin has hepatoprotective action against carbon tetrachloride induced hepatic damage in rats. There was decreased activitiy of glutathione Stransferase and glutathione reductase; and they were restored towards normalization. Rubiadin inhibited the elevation of hepatic malondialdehyde formation and depletion of reduced glutathione content in the liver, in a dose dependent manner. 87

\section{Anti-proliferavtive activity}

In an experiment Rubiadin was isolated from the roots of $R$. cordifolia, where it has shown to possess in vitro antiproliferative activity. Rubiadin was subjected for the inhibition of the enzyme EGFR tyrosine kinase in molecular docking, which is one of the targets for inhibition of cancer cells. ${ }^{8}$

Ethyl acetate (EA) fraction of Radix Rubiae strongly suggests its anti-psoriatic activity since it inhibits cell growth and promotes terminal differentiation in cultured human keratinocytes. 89

\section{Anti-diabetic activity}

In an experiment, animal model was tested with alcoholic extract of root of $R$. cordifolia, where it was found to have promising antidiabetic activity. The extract of roots was given to normal, glucose fed and alloxan induced diabetic rats, where it showed decrease in blood glucose level, it reduced the blood sugar level in alloxan treated diabetic rats as well, indicates that the extract has an extra pancreatic effect. 90

The rats when treated with Aqueous extract of Rubia cordifolia improved oral glucose tolerance by compared to glucose fed animals, exogenously injected insulin along with the drug extract caused potentiation of hypoglycaemic effect as compared with alone insulin treatment. ${ }^{91}$

The leaf extract decreased the blood glucose level compared to the glibenclamide in both normal fasted rats and alloxaninduced diabetic rats. The extract also showed a favourable effect on glucose disposition in glucose-fed hyperglycemic rats. There was also reduction in serum cholesterol and triglyceride levels, whereas elevation in serum high density lipoprotein and protein level in diabetic rats. 92

\section{Nephroprotective Activity}

In an experiment where swiss albino rat model was used, hydro-alcoholic extract of Rubia cordifolia has shown decrease in intensity of cisplatin induced nephrotoxicity due to antioxidant property present in the drug. There were remarkable changes in the serum creatinine and urea levels. 24

Hydro alcoholic extract of $R$. cordifolia can protect against ethylene glycol induced urolithiasis as it reduced and prevented the growth of urinary stones, because it significantly reverts the increased calcium and oxalate levels and number of calcium oxalate crystals depots in the kidney tissue of calculogenic rats. ${ }^{93}$

\section{Cardioprotective}

It can work in arrhythmias because it has got spasmolytic activity which is suggestive of presence of calcium channel blocker like constituents in this plant. 94

Diuretic activity of Rubia cordifolia, has proven to be effective against the management of odema, therefore it could be alternative therapy in the management of congestive heart failure (CHF). Also Antihyperglycemic and antihyperlipidemic effects of rubia can also work cardiomyopathy and diabetic macrovascular disease. 22

\section{CONCLUSION}

Recently there is increase in use of traditional medicines to cure various ailments and prescribing combination therapy for many diseases. This has led to an increase chance of drug interaction and adverse effects, means there is need to evaluate individual herbal therapy. Rubia cordifolia is an ethno botanical plant which is abundant in constituents which are having marvellous properties to treat different pathologies and to combat them. The plant is well tested for its efficacy and is believed to be safe for human use. But there are many adulterants present in the market by its name. So as to get the required results it is necessary to avoid any such interchanging for that pharmacogonstical study is need to be done properly. The reported phytochemicals and pharmacological studies supports its long traditional use due to presence of anthraquinones, glycosides, saponins, steroids, phenols, and flavonoids etc, which are responsible for different actions like potent blood purifier, antioxidant, anti-inflammatory, immune modulator, antistress, antimicrobial, hypoglycemic, hepatoprotctive, anti-cancerous, cardio and nephro protective. More studies are yet to be done on these active components to explore the therapeutic potential of the plant. And this review might help to open more doors of research in future.

\section{REFRENCES}

1. Verma A, Kumar B, Alam P, Singh V and Gupta SK, Rubia Cordifolia-A Review on Pharmaconosy and Phytochemistry, Int J Pharm Sci Res, 2016; 7(7): 2720-31.

2. McIntyre A, Monographs of Ayurvedic herbs commonly used in the treatment of children-Herbal treatment of children, 2005; 87-135.

3. Prajapathi ND and Kumar U, Dictionary of Medicinal Plants, Agrobios, Jodhpur, 2003; 294.

4. Sivarajan, VV and Balachandran, I, Ayurvedic Drugs and Their Plant Sources, Oxford \& IBH Publishing Co. 1994.

5. Pandey BP, Taxonomy Anatomy Economic Botany \& Embryology for Degree Students (S.Chand \& Company Ltd., New Delhi) First edition, 1981; 183.

6. Kabiruddin AM, Makhzunul Mufradat, Delhi, Idara kitab ush shifa, 2007; 303.

7. Siva Rami Reddy E, A complete review on Rubia cordifoila International $\mathrm{J}$ of Trend in Scientific Research and Develpoment, vol 2, Issue 2, ISSN N:2456-6470 www.ijtsrd.com

8. Bhatt NS, Deshpande M, Pharmacognostic studies on Identity of Manjishtha-Rubia cordifolia Linn- An Ayurvedic plant, IOSR Journal of Pharmacy Volume 5, Issue 3 2015; 06-12.

9. Jain SK and DeFillips RA, Medicinal Plants of India, Vol. 2. Reference Publications, Algonac, MI, 1991; 558.

10. Hooker JD, the Flora of British India, Vol III, L. Reeve \& Co, London. 1882; 202- 204.

11. Kannan M, Singh and Narayanan, Phytochemistry and Immunopharmacological Investigation of Rubia cordifolia Linn. (Rubiaceae) Pharmacologyonline, 2009; 3: 653-662.

12. Deshkar N, Tilloo S and Pande V, Phcog Rev: Review Article a Comprehensive Review of Rubia cordifolia Linn. Pharmacognosy Reviews Vol 2, Issue 3, Jan-Jun, 2008. 
13. Shethashok k, The herbs of Ayurveda, vol-4, 1st edition, 2005; 98.

14. More DB, Gajarmal AA and Shende MB, Comparitive studies of different samples of Manjishtha (Rubia cordifolia Linn) W.S.R. To Deshvichara-A Review, Int.J of Ayurveda and herbal medicine 2014; 4(5):1579-1584.

15. Devi PM and Siril EA, Pharmacognostic Studies on Indian Madder (Rubia cordifolia L.), Journal of Pharmacognosy and Phytochemistry, Vol. 1 No. 5 2013; 12. www.phytojournal.com

16. Bhat BA, Shergojri FA, Gaur $M$ and Shammi QJ, A Comprehensive Review On Rubia Cardifolia (Manjistha), 2018. www.conferenceworld.in

17. Rubia root (Qiancao)-Rubia cordifolia-Radix Rubiae, 2012. www.epharmacognosy.com

18. Nabi MG, Makhzanul mufradat wa murakbat (Khaas Advia), Matba Iftekhar Delhi.

19. Kirtikar KR and Basu BD, Indian Medicinal Plants, Vol-2, Lalit Mohan Basu, Allahabad, 1981.

20. Singh BP, Dadich OP and Deepa, A review study of medicinal uses of Manjishtha ( $R$. cordifolia), Int. J. Adv. Res. 5(8);13941401.

21. Antarkar DS, Bhatt $\mathrm{N}$, Chinwalla $\mathrm{T}$ and Vaidya $\mathrm{ADB}$, Indian Journal of Pharmaceutics, 1984; 15(3);185-188.

22. Bhatt P, Kushwah A, Rubia cordifolia Overview: A New Approach to Treat Cardiac Disorders, International Journal of Drug Development \& Research, April 2013; 5:7-54.

23. Kabeeruddin H, Makhzanul Mufradat Khwas ul Advia, Sheikh Mohd Basheer and Sons, waqf Jalal Uddin building, chok Urdu bazar, Lahore, 417.

24. Joy J, Krishnan C and Nair K, Amelioration of cisplatin induced nephrotoxicity in Swiss albino mice by Rubia cordifolia extract, J of Cancer Res Ther, 2008; 4(3).

25. Bhardwaj HC and Jain KK, Indian dyes and dying industry in 18-19 century, Indian J of History of Science, 17(1):78-81.

26. Gogte VVM, Ayurvedic pharmacology and therapeutic uses of medicinal plants, Bharatiya Vidya Bhavan, Mumbai, 2000.

27. Razi Z, Kitab ul Hawi, vol 10, Central Council of Research in Unani Medicine, New Delhi, 52.

28. Ali HMS, Unani Advia Mufarredah 2010; 211.

29. Lateef HA, Qarabdine Mjeedi, Ajanta office and packaging limited, Delhi 1984; 123.

30. National Formulary of Unani Medicine vol $4^{\text {th }}$, Central Council of Research in Unani Medicine, Ministry of Health and Family Welfare, 2011; 68

31. Kabiruddin HM, Moaljate Shareh Asbab, vol 2, Aijaz publication house, 2:176.

32. National Formulary of Unani Medicine Part 2 nd vol $1^{\text {st }}$, Central Council of Research in Unani Medicine, Ministry of Health and Family Welfare, 2007; 68:71.

33. Meena V, Chaudharuy AK, Manjishtha (R.cordifolia) : A helping herb in cure of acne, Jour. of Ayurveda a holistic and Medicine, vol 3 Issue 2 EISSN: 3(2):2321-1563.

34. Khare CP, Encyclopedia of Indian Medicinal Plants, Springer, Germany, 2004; 405-406.

35. Kim KJ, Lee JS, Kwak MK, Choi HG, Yong CS, Kim JA, Lee YR, Lyoo WS and Park YJ: Anti-inflammatory action of mollugin and its synthetic derivatives in HT-29 human colonic epithelial cells is mediated through inhibition of NF- $\kappa \mathrm{B}$ activation. European Journal of Pharmacology, 2009; 622:52-57.

36. Tsewang JT, Tibetan Medicinal plants, Tibetan medical publication, India, 1994; 132.

37. Wiart C, Ethnopharmacology of Medicinal plants-Asia and the Pacific, Human Press, New Jersey, 2006; 83-85.

38. Maithy, Folk uses of some medicinal plants from north Sikkim, Indian Journal of Traditional Knowledge, 2004; 69.

39. Bhosle SV, Ghule VP, Aundhe DJ, Jagtap SD, Ethenomedical Knowledge of plants used by the tribal people of Purandhar in Maharashtra India, Ethnobotanical leaflet, 2009; 13:13521361.

40. Thomas B, Rajendran A, Less known ethno medical plants used by kurichar tribe of Wayanad district, southern western ghats, Kerala, India, Botany Res. Int., 2013; 6:32-35.

41. Kar T, Mandal KK, Reddy CS, Biswal AK, Ethnomedicinal plants used to cure Diarrhoea, Dysentry and Cholera by some tribes of Mayurbhanj district, Odisha, India, Life Sci. leaflets, 2013; 2:18-28.
42. Padal SB, Raju JB, Chandrasekhar P, Traditional Knowledge of Konda Dora tribes, Visakhapatnam district, Andhra Pradesh, Indian Journal Pharmacy, 2013; 3: 23-28.

43. Bhatt D, Kumar R, Joshi GC, Tewari LM, Indigenous uses of medicinal plants by the Vanraji tribes of Kumaun Himalya, Indian Journal Medicinal Plants Res, 2013; 7:2747-2754.

44. Jayakumar G, Ajithabai MD, Sreedevi S, Vishwanathan PK, Keemsh kumar B, Ethnobotanical survey of the plants used in the treatment of diabetes, Indian Journal Traditional Knowledge, 2010; 9:100-104.

45. Singh $\mathrm{P}$ and SJ Ali, (Ethenomedicinal plants of family Rubiaceae of eastern U.P, Indian J.L.Sci., L,2012; 83-86.

46. Rubia+cordifolia, 2007. http://www.ibiblio.org/pfo.f/cgiBin/arr_html

47. Ssegawa P, Kasenene JM, Medicinal plant diversity and uses in the Sango bay area, Southern Uganda, J. Ethnopharmacology, Sep 25, 2007; 113(3):521-540.

48. Mishchenko NP, Fedoreev SA, Bryukhaov VM, Zverev YF, Lampatov VV, Azarova OV, Shkryl YN and Chernoded GK, Chemical Composition and Pharmacological Activity of Anthraquinones from Rubia cordifolia Cell Culture, Pharmaceutical Chemistry Journal, 2007; 41(11):605-609.

49. Itokawa H, Mihara K, Takeya K, Chem. Pharm. Bull, 1983; 31:2353-2358.

50. Singh N and Singh M, Preliminary Photochemical Investigation of Ethanolic and Petroleum Ether Extracts of Rubia cordifolia Leaves, Asian Journal of Pharmaceutical Education and Research ISSN: 2015; 4(3):2278-7496.

51. Dengre RG, Patel KN and Chauhan MB, Comparative studies of Rubia cordifoilia linn. And Rubia tinctorium linn (Rubiaece) Ancient Science of Life 13. Vol No. XIII Nos. 1 \& 2, July-October 1993; 8(1):165-179.

52. Gupta PP, Srimal RC, Verma N and Toandon JS, Biological activity and isolation of an active principle, Pharm biology, 1999; 37(10):46-49.

53. Tripathi YB, Sharma M, Shukla S, Tripathi P, Thyagaraju K, Reddanna P, Rubia cordifolia inhibits potato lipoxygenase, Indian J. Exp. Biol., 995; 33:109-112.

54. Joharapurkar AA, Zambad SP, Wanjari MM and Umathe SN, In vivo evaluation of antioxidant activity of alcoholic extract of Rubia cordifolia linn. and its influence on ethanol-induced Immunosuppression, Indian Journal of Pharmacology 2003; 35:232-236.

55. Biswas TK, Mukherjee B, Roy JB, Plant medicines of Indian origin for wound healing activity: A review, Int. J. Low Extrem. Wounds, 2, 2003; 25-39.

56. Gupta M, Yadav SK, Singh D and Gupta N, Evaluation of wound healing activity of herbal drug combination of Rubia cordifolia, Centella Asiatica, Terminalia belerica, plumbago, Zeylanica and Withania Somnifera, International journal of Pharmaceutical and life science, 2011; 2(7):952-952.

57. Karodi R, Jadhav M, Rub R, Bafna A, Evaluation of the wound healing activity of a crude extract of Rubia cordifolia L. (Indian madder) in mice, Int. J. Applied Res.Natl. Products, 2009; 2:1218.

58. Tripath YB, Sharma M, and Manickam M, Rubiadin a new antioxidant from Rubia cordifolia, Ind. J. Biochem. Biophys. 1997: 34:302-306.

59. Pawar AT, Kalyani D, Chandrasekar SB and Divakr G, Diuretic activity of root extract of Rubia cordifolia linn. Pharmacologyonline, 2009: 1:597-603.

60. Naidu KC, Lalram R, Bobbarala V, Antimicrobial agents from Rubia cordifolia and Glycyrrhiza glabra against pathogens of Gossypium, Int. J Pharma. Tech. Res., 2009; 1:1512-1518.

61. Mariselvam R, Ranjit Singh AJA, Nanthini AUR, Preparation and characterisation of Silver nanoparticles using Rubia cordifolia plant root extract and the microbial properties,Int.J Adv Res., 2013; 1:56-61.

62. Basu, Ghosh A, Hazra B, Evaluation of the antibacterial activity of Ventilago madraspatana Gaertn, Rubia cordifolia Linn. and Lantana camara Linn, Isolation of emodin and physcion as active antibacterial agents, Phytother Res., 2005; 19(10):88894.

63. Qiao YF, Wang SX, Wu LJ, Li X, Zhu TR, Studies on antibacterial constituents from the roots of Rubia cordifolia L. Yao Hsueh Hsueh Pao (Acta Pharmaceutica Sinica), 1990; 25(11):834-9. 
64. Tripathi YB, Pandey S, Shukla SD, Anti-platelet activating factor property of Rubia cordifolia Linn., Indian J. Exp. Biol., 1993; 31(6):533-5.

65. Tripathi YB, Singh AV, Role of Rubia cordifolia Linn in radiation protection, Indian J. of Experimental Biology, 2007; 45:620-625.

66. Shah V, Kumar S, Maurya DK, and Nair CKK, Protection of plasmid pBR322 DNA and membranes of rat liver microsome and mitochondria by Rubia cordifolia extract, Ind. J. Radiat. Re., 2004; 1:46.

67. Prajapati SN and Parmar KA, Anti-viral and in-vitro free radical scavenging activity of leaves of Rubia cordifolia, International Journal of Phytomedicine, 2011; 3:98-107.

68. Gupta M, Shaw BP and Mukerjee A, studies on AntipyreticAnalgesic and Ulcerative activity of polyherbal preparation in Rats and mice, Int.J. Pharmacol, 2008; 4:88-94.

69. Deoda RS, Kumar D, and Bhujbal SS, Gastroprotective effect of Rubia cordifolia Linn. on Aspirin plus Pylorus-ligated Ulcer BMC Complem. Altern. M., 41624, 2011.

70. Pawar AT, Anap MP, Ghodasara JV and Kuchekar BS, Protective Effect of Hydroalcoholic Root Extract of Rubia cordifolia in Indomethacin-Induced Enterocolitis in Rats, Indian J Pharm Sci, 2011; 73(2):250-253.

71. Kasture VS, Deshmukh VK and Chopde CT, Anti convulscent and behavioural action of triterpene isolated from Rubia cordifolia linn, Indian J.Exp.Biol., 2008; 38:675-680.

72. Aslam M, Imtiyaz S, Tariq M, Chaudhary SS, Ahmed K, Unani immunomodulating Drugs: An overview, Int.J. Med. Pharm. Sci. Res. Review, 2013; 1-10.

73. Pandey S, Sharma M, Chatyrvedi P, Tripathi YB, Protective effect of RC on lipid peroxide formation in isolated rat liver homogenate, Ind. Journal of Experimental Biology, 1994; 32(3):180.

74. Tripathi $\mathrm{YB}$, Sharma M, The interaction of RC with iron redox status A mechanistic aspect in 42. free radical reactions, Phytomedicine, 1999; 6(1): 51-57.

75. Patil R, Gadakh R, Gound H, Kasture S, Antioxidant and Anticholinergic Activity of Rubia Cordifolia, Pharmacologyonline, 2011; 2:272-278.

76. Tripathi YB, Shukla S, Sharma M, Shukla VK, Antioxidan property of Rubia cordifolia extract and its comparison with vitamin E and parabenzoquinone, Phytother. Res., 1995; 9:440-443.

77. Garle AM, Patil SS, Evaluation of antioxidant and Anti Acne property of R cordifolia, Der Pharmacia Sinica, 2010; 1(3):5963.

78. Jain A, Bansal E, Inhibiton of propionibacterium acnes-induced mediators of inflammation by Indian herbs, phytomedicine, 2003; 10:34-38.

79. Zhang $\mathrm{ZH}$, Clinical observation on the increase of leukocyte count in leukopenia promoted by diethylester Rubia cordifolia Linn, Zhong Xi Yi Jie He Za Zhi, 1983; 3(2):98-9.

80. Adwankar MK and Chitnis MP, In vivo anti-cancer activity of RC-18: A plant isolate from Rubia cordifolia Linn. against a spectrum of experimental tumour models, Chemotherapy 1982; 28(4):291-293.

81. Chang LC, ChaÂvez D, Gills JJ, Fong HHS, Pezzuto JM and Kinghorn AD, Rubiasins A-C, new anthracene derivatives from the roots and stems of Rubia cordifolia, Tetrahedron Letters, 2000; 41(37):7157-7162.

82. Patel PR, Raval BP, Karanth HA and Patel VR, Potent antitumor activity of Rubia cordifolia, International Journal of Phytomedicine, 2010; 2:44-46.

83. Gupta PP, Srimal RC, Verma N, Tandon JS, Biological Activity of Rubia cordifolia and Isolation of an Active Principle, Pharmaceutical Biology, 1999; 37(1):46-49.

84. SON JK, JUNG SJ, JUNG JH, FANG Z, LEE CS, SEO CS, MOON DC MIN BS, KIM MR and WOO MH, Anticancer Constituents from the Roots of Rubia cordifolia L, Chem. Pharm. Bull, 2008; 56(2):213-216.

85. Gilani AH, Janbaz KH, Effect of Rubia cordifolia extract on acetaminophen and CCl4-induced hepatotoxicity, Phytotherapy Research, 1995; 9(5):372-375.

86. Babita MH, Chhaya G, Goldee P, Hepatoprotective activity of Rubia cordifolia, pharmacologyonline, 2007; 3:73-79.

87. Rao GM, Rao CV, Pushpangadan P, Shirwaikar A, Hepatoprotective effects of rubiadin, a major constituent of Rubia cordifolia Linn., J Ethnopharmacol, 2006; 103(3):48490.

88. Paarakh PM, Sreeram DC, SD S, PS SG, AB V, In vitro Antiproliferative and in silico acytivity of Rubiadin isolated from roots of Rubia Cordifolia, Mintage J. of Pharmaceutical and medical sciences, 2016; 5(1).

89. Zhou LL, Lin ZX, Fung KP, Che CT, Zhao M, Cheng CHK, Zuo Z, Ethyl acetate fraction of Radix rubiae inhibits cell growth and promotes terminal differentiation in cultured human keratinocytes, Journal of Ethnopharmacology, 2012; 142: 241 247.

90. Patil RA, Jagdale SC, Kasture SB, Antihyperglycemic, Antistress and Nootropic activity of roots of Rubia cordifolia linn, Ind. J. Exp. Biol., 2006; 44:987-992.

91. Somani SR, Jain SK, Singhai AK, Hypoglycaemic activity of roots of rubia cordifolia in normal and diabetic rats, Pharmacologyonline, 2007; 1:162-169.

92. Viswanathaswamy AHM, Koti BC, Singh AK, Thippeswamy AHM, Antihyperglycemic and antihyperlipidemic effect of Rubia cordifolia leaf extract on Alloxan-induced Diabetes, RJPS, 2011; 1:49-52.

93. Divakar K, Pawar AT, Chandrasekhar SB, Dighe SB, Divakar G, Protective effect of the hydro-alcoholic extract of Rubia cordifolia roots against ethylene glycol induced urolithiasis in rats, Food Chem Toxicol, 2010; 48(4):1013-1018.

94. Gilani AH, Janbaz KH, Zaman M, Lateef A, Suria A, Ahmed HR, Possible presence of calcium channel blocker(s) in Rubia cordifolia: An indigenous medicinal plant, J Pak Med Assoc., 1994; 44(4): 82- 85 . 